\title{
Fulfilling U.S. Commitments to Its Afghan Allies
}

For 17 fraught days in August, the world watched as U.S. and allied forces launched a chaotic evacuation out of Afghanistan. The operation was both massive in size and incredibly precarious - as the U.S. relied on its 20-year enemy for assistance, and the threat of terrorist attacks mounted by the day. Now that the large-scale evacuation of Americans and Afghans is over, and many evacuees are making their way to the United States, it is becoming clearer how much of the intended mission still lies ahead.

Within the impressive achievement of bringing 124,000 people to safety, the United States fell far short of its goal of rescuing those who risked their lives to support the U.S. war and state-building effort. Reaching and evacuating them will need to continue into the months and years ahead. Meanwhile, the tens of thousands of Afghan evacuees now in the United States are in need of a durable legal status and access to services to set them up for economic and social stability.

Throughout its war in Afghanistan, the United States relied on two forms of the Special Immigrant Visa (SIV), created in 2006 and 2009, to protect Afghans allies. SIVs are available for Afghans employed by the U.S. government, its contractors or allied forces. Through June 2021, nearly 77,000 Afghans had reached the United States on an SIV - more than the number of Afghan refugees the United States absorbed during the 20 -year war.

The 14-step process of obtaining an SIV is arduous and slow. It starts with documenting ongoing threats as a consequence of working for the U.S. government and obtaining a letter of recommendation from a U.S. citizen supervisor. Many would-be applicants are stymied from the start because they cannot reach supervisors with whom they have been out of touch for years, or because their supervisors worked at contracting firms that no longer exist. The final steps of the process consist of an interview, security and background checks that can stretch on for months, and a health screening.

Once the U.S. finalized its withdrawal date, it became clear that the SIV process could never be sufficient for bringing Afghan allies to safety in time. This spring, the SIV application backlog stood at around 17,000, most including several family members as dependents. Despite a Congressional mandate to process SIVs within nine months, the government was averaging over two years. The Biden administration rushed additional staff to process SIVs, which sped approvals up to a rate of 1,000 per week by early August. But as the withdrawal deadline approached and the Taliban gained ground, it was evident that no level of resources would be sufficient to process all the applications in time. Advocates pressured the Biden administration to evacuate Afghans allies to another location - such as a U.S. territory used in the past for Vietnamese evacuees - for safety during ongoing processing.

The Biden administration did not announce an evacuation strategy for SIV applicants until mid-July, seven weeks before the withdrawal deadline. The announced plan was to bring about 2,500 Afghans who were far along in the SIV process to the United States to complete processing, and to locate a third country where Afghans in earlier stages of the process could reside while their applications were adjudicated. However, on the weekend of August 14-15, as the Taliban approached Kabul, the State Department was reportedly still scrambling to secure an overseas partner.

(c) The Author(s) 2021. Open Access: This article is distributed under the terms of the Creative Commons Attribution 4.0 International License (https://creativecommons.org/licenses/by/4.0/).

Open Access funding provided by ZBW - Leibniz Information Centre for Economics.
Julia Gelatt, Migration Policy Institute, Washington DC, USA. 
Once Kabul fell, this plan crumbled, and the United States switched to evacuation mode. Despite chaos around the airport, confusion amidst uncoordinated efforts by NATO allies, and Afghans' difficulties getting past Taliban checkpoints, the U.S. eventually aided in the evacuation of 124,000 people. By all accounts, most of those evacuees were not in the SIV pipeline, and the great majority of SIV applicants were left behind. However, many likely aided in U.S. military and development efforts in other ways, raising questions about whom the United States owes assistance, and how many Afghans it intends to help.

Under the current law, most Afghans who made it to the United States will receive very limited social assistance. The U.S. expects to receive about 65,000 Afghans in the short term and another 30,000 in the year ahead. The majority are arriving through the humanitarian parole process - meaning they do not have a visa, but are allowed in under executive authority. SIV recipients and applicants will be entitled to the full set of services given to refugees for up to five years, including help with housing, English instruction, job placement services, and special access to public benefits. Those not in the SIV pipeline are eligible for only nine months of assistance and extremely limited access to public benefits.

Entering through parole leaves Afghan evacuees in an unstable legal status. Parole provides short-term permission to live and work in the country, but no path to permanent residence. Parolees not in the SIV pipeline would need to go through the rigorous asylum application process to secure a durable status. However, adding tens of thousands of Afghans to the affirmative asylum backlog, which is 400,000 deep, will only strain an already overstretched system. And given the complexity of the asylum process, applicants often seek legal counsel. But the country's network of legal service providers is also overstretched. Many Afghans could end up in legal limbo.

Congress appears poised to address evacuees' resettlement needs, but not their legal status. President Biden asked Congress to make all Afghan evacuees eligible for full refugee resettlement services, and to open lawful permanent residence to evacuees after a year in the United States as part of a spending bill that must pass by September 30. The measure currently before Congress would provide broader social assistance to all Afghan evacuees. However, instead of offering a path to permanent residence, it would require the U.S. government to expedite Afghans' asylum applications. Congress could still address Afghan's immigration status in future legislation - if enough Republicans will get on board.

The U.S. commitment to its allies requires not only supporting their path to stability within the United States, but also rescuing allies - however defined - left behind. This protection will likely take several forms. Veterans and U.S.-based Afghan family members are furiously applying for humanitarian parole for Afghans still in the country. Refugee resettlement is also an option; the Biden administration has set a fiscal 2022 target of resettling 35,000 refugees from the world region that includes Afghanistan. As part of that number, the United States has created a special pathway for Afghans who do not qualify for an SIV but have worked for the U.S. government or a U.S.-based non-governmental or media organization.

Other options for helping Afghan allies could include the creation of a dedicated parole program, as the U.S. did in the past for Cubans, Haitians and Central American minors. But any of these pathways, as well as ongoing SIV processing, would require Afghans to make their way out of Afghanistan to a place where the U.S. government has a presence. Therefore, a necessary complement to these plans must be ongoing cooperation with international partners in keeping international flights running and securing land routes out of the country.

The United States proved in August that it had the ability and the will to marshal incredible resources to fulfill its commitments to Afghan allies. Now President Biden and Congress must finish the job by providing Afghans in the United States with the resources and status they need to launch their lives in a new country, and continuing to work to rescue allies left behind. 